\title{
When Does Diffusing Protest Lead to Local Organization Building? Evidence from a Comparative Subnational Study of Russia's "For Fair Elections" Movement
}

\author{
Jan Matti Dollbaum
}

\begin{abstract}
Under what conditions do nation-wide mass protests in authoritarian regimes produce new local activist organizations? Based on sixtyfive interviews and over 1,000 media reports, internal documents, and social media posts, I compare the organization-building process in the "For Fair Elections" (FFE) protests of 2011-2012 across four Russian regions. I argue that mass protests are more likely to leave behind new social movement organizations (SMOs) when the local and the national interact, i.e., when long-standing activists on the ground perceive an opportunity to use the protests for their ongoing local struggles. Where new SMOs are established, their composition, activity pattern, and inner structure follow the tactical and organizational repertoires of veteran activists that were shaped by their local political environments. This argument illuminates the functioning of electoral authoritarian regimes from a subnational perspective and identifies conditions under which a bottom-up challenge to an authoritarian political system can drive local civil society development.
\end{abstract}

V hen tens of thousands of citizens filled the streets of Russian cities to protest fraudulent parliamentary elections in December 2011, the hopes for resurging civic engagement and imminent democratic change were high. After some first concessions, however, high expectations gave way to frustration. The regime stepped up its repressive response (Gel'man 2015) and orchestrated a broad legislative and discursive backlash (Laruelle 2013; Smyth, Sobolev, and Soboleva 2013). Meanwhile, the "For Fair Elections" (FFE) movement fractured: numerous leaders and activists emigrated, others undertook fruitless attempts at entering the tightly controlled political arena (Lasnier 2018), and many simply retracted from the public sphere.

I set aside these normative perspectives-the enthusiasm and the frustration - and assess their empirical implications for local activism, asking under what conditions nationwide protests in an electoral authoritarian setting can produce new local activist organizations. While classical social movement scholarship assumes that protest cycles produce new organizations (McAdam 1999) that can form the backbone of renewed mobilization (Taylor 1989), Robertson (2011) argues that in hybrid regimes, there may be much protest without accompanying civil society

A list of permanent links to Supplemental Materials provided by the author precedes the References section.

*Data replication sets are available in Harvard Dataverse at: https://doi.org/10.7910/DVN/D3OC1H

Jan Matti Dollbaum (D) is currently a post-doctoral researcher at the Research Center for East European Studies at the University of Bremen (dollbaum@uni-bremen.de). His main focus lies on contentious politics in authoritarian regimes, their functioning, and their stability. He is working on a book project tentatively entitled "A Movement's Troubled Legacy: Protest and Activism in Russia's Regions after the "For Fair Elections" Movement". He received his PhD from the University of Bremen in 2020.

He thanks Ivan Bakalov, Heiko Pleines, Graeme Robertson, and Regina Smyth as well as commentators at the annual meetings of the American Political Science Association and the Association for Slavic, East European, and Eurasian Studies in 2018 for their very thoughtful and constructive comments at various stages of the research process. He also thanks four anonymous reviewers and the editor of Perspectives on Politics for excellent suggestions that substantially improved the text. This article was produced as part of the research project "Comparing Protest Actions in Soviet and Post-Soviet Spaces_Part 2," which is organized by the Research Centre for East European Studies at the University of Bremen with financial support from the Volkswagen Foundation. 
growth. The specific conditions under which protest does lead to organization building in authoritarian regimes, meanwhile, are highly under-theorized (Lasnier 2017).

Drawing on sixty-five semi-structured interviews, over a thousand media reports, and over one hundred internal documents and social media posts, I trace the organization-building process during the Russian "For Fair Elections" (FFE) protests of 2011-2012 across four subnational cases, proposing a novel argument that proceeds in three steps: First, in the years preceding the onset of a wave of mass protest, local activists develop distinct repertoires (Tilly 2008; Clemens 1997), the shape of which depends on activists' local political conditions. More open, more resourceful, and less repressive political climates tend to generate broader tactical and more inclusive organizational repertoires than do less pluralist, less resourceful, and more repressive contexts. Second, where established activists perceive an opportunity to employ the erupting mobilization for their local struggles, this increases the likelihood that mass protests produce new local social movement organizations (SMOs). Third, how the new SMOs are structured depends on the repertoires from earlier episodes of contention that established activists use as templates for their organizational choices.

The argument speaks to several strands of literature. First, it illuminates within-country differences in opposition action and the functioning of modern authoritarian regimes (Giraudy, Moncada, and Snyder 2019). Second, it contributes to the underdeveloped research program on protest institutionalization in non-democratic settings (Lasnier 2017), highlighting the importance of varieties of authoritarianism (e.g., Howard and Roessler 2006) for social movement theory. Third, by substantiating the research agenda that understands protests as critical junctures (Blee 2012; della Porta 2018), it provides an interactive model of structure and agency (Fligstein and McAdam 2011).

There are three reasons why the Russian case is well suited to yield results of more general relevance. First, it is an exemplary case of an electoral authoritarian system, in which national elections are controlled to an extent that precludes any real uncertainty (Levitsky and Way 2010), but nevertheless produce "focal points" (Tucker 2007) for opposition to mobilize around. Second, the FFE protests, though not successful at bringing about democratic change, share many other attributes with "urban civic revolutions" (Beissinger 2013): They were triggered by fraudulent parliamentary elections, they proceeded mainly in urban spaces, and they brought together citizens with great ideological differences, pressing demands for free and fair elections without articulating a specific political program or social vision (see also Bunce and Wolchik 2010). Finally, Russia displays large structural variations on the subnational level that amount to the difference between competitive and hegemonic authoritarian regimes (Libman 2017; Ross and Panov 2019). Leveraging this within-country variation allows for a comparison of crossnationally meaningful structural differences while simultaneously controlling for factors that confound crosscountry comparisons.

\section{Diffusion and Institutionalization of Protest}

Resource Mobilization Theory (RMT) has long argued that SMOs are important for protest mobilization, because they are "bundlers and spenders" of resources like finances, connections, and knowledge (Earl 2015; see also McAdam 1986; Greene 2013). Moreover, RMT has convincingly shown that organizations are vital to uphold a movement in times of low societal mobilization through conserving frames, identities, and tactics (Taylor 1989; Staggenborg 1998; see also Earl 2015).

The empirical record on the reverse-the impact of protest on organization building - so far is inconclusive (Soule and Roggeband 2018). On the one hand, McAdam expects protest cycles to produce formal organizations due to their greater organizational capacities compared to grass-roots groups (McAdam 1999, 147). On the other hand, there is evidence that with rising protest levels the rate of organization building declines (Minkoff 1997; Meyer and Minkoff 2004).

Systematically addressing this question in an electoral authoritarian context can help to close a persisting gap in the literature on protest institutionalization. This process is seldom studied outside of Western liberal democracies. Moreover, the few existing comparative works (e.g., Tarrow and Tilly 2007) have not embraced the diversity of authoritarian regimes and thus often equate nondemocratic rule with closed authoritarianism (Moss 2014), glossing over more subtle but causally important differences. Bringing in the framework of varieties of authoritarianism can thus help to move the debate forward.

\section{A Theory of Organization Building in Diffusing Mass Protest}

In defining the dependent variable, I make use of Ahrne and Brunsson's (2011) concept of "partial organizing," since it adequately captures the varieties of meaningful formalization for SMOs that do not officially register as judicial entities. Its flexibility makes the concept particularly useful for non-democratic contexts, where registration often exposes organizations to repression or obstruction, and is thus sometimes avoided (Moser and Skripchenko 2018). In this study, I define organization building as the founding of a new SMO that is visible to the outside and entails clear decisions on membership (Ahrne and Brunsson 2011, 85-87). ${ }^{1}$

The argument proposed later will be embedded in an analytical framework that treats protests as critical junctures (Blee 2012; della Porta 2018). These are moments of 
uncertainty, in which agents' choices have great consequences: "Once a particular option is selected it becomes progressively more difficult to return to the initial point when multiple alternatives were still available" (Mahoney 2000, 513). However, contingency at the time of a decision does not mean a structural blank slate (Thelen 2003). Instead, critical antecedents that precede a critical juncture constrain the choice of agents (Capoccia 2015), "combin[ing] in a causal sequence with factors during a critical juncture to produce divergent long-term outcomes" (Slater and Simmons 2010, 887). Following this reasoning, mass protests that diffuse to different localities are conceptualized here as critical junctures during which actors make choices for or against organization building and the inner structure of new SMOs-choices that are constrained by their local preconditions. In the following, I present this argument in three steps that match the constituent elements of the analytical framework: the critical antecedents, the critical juncture, and the outcome.

\section{The Critical Antecedents: Local Political Structures and Activists' Repertoires}

In this first step I argue that structural features of activists' local political environments do not directly predict whether and how activists will build organizations during protest. However, these local structures - in particular the local political opportunity structures (Kriesi et al. 1992) and the availability of allies and economic resources-do play an important part in the organization building process, because they shape the repertoires that local activists develop before the onset of the critical juncture and that constrain them in their tactical and organizational choices.

Repertoire is defined by Charles Tilly as "the whole set of means that a group has for making claims" (Tilly 1986, 4). In several influential works, Tilly established two basic points, both of which this first step of the argument draws upon. First, the set of options that actors can choose from is quite literally limited in each given moment: "In something like the style of theatrical performers, participants in contention are enacting available scripts," with innovation happening mostly within or close to these scripts (Tilly 2008, 15; also Tarrow 1998). Second, repertoires develop in close interaction with the structural environments that activists find themselves in (Oliver and Myers 2002; Tilly 2008; Robertson 2011). More specifically, pluralist contexts with open political climates and little repression tend to have broad tactical and inclusive organizational repertoires. By contrast, where contact points to authorities are few, resources are sparse, and repression against political contenders, media, and activists is a real possibility, repertoires can be expected to be narrower and less diverse (see also Maloney, Smith, and Stoker 2000), with higher repression tightening the bonds between those who dare to resist it by nurturing an "'us' versus 'them' distinction" (Fox 1996, 1091).
The concept of repertoire comprises tactics and organizational forms. ${ }^{2}$ Tactics refers to the set of action forms available to local activists-be it direct action like strikes and blockades, symbolic protest forms like demonstrations or petitions, or less contentious tactics like public discussions and roundtables that seek to implement dialogue with authorities. Organizational repertoires are defined as "a type of competence, a set of familiar patterns for ordering social relations and action” (Clemens 1997, 48) -tried-and-tested organizational models available to activists from cultural socialization or earlier periods of contention. These repertoires may concern how different local actors and groups cooperate (e.g., coalitions versus isolated action) or how existing activist groups are structured (e.g., hierarchy versus horizontality). These repertoires evolve slowly and are shaped by activists' structural environments and thus vary across states, and-to the extent that regime features vary subnationally (see Fox 1996)_also across regions and cities.

\section{The Critical Juncture: Diffusing Mass Protest}

The second step of the argument concerns the critical juncture itself. A critical juncture here is conceptualized as the high mobilization phase of a broad and inclusive protest cycle. It is a critical juncture because it brings together an unusual diversity of actors in unexpected quantities - parties, NGOs, and trade unions, but also unaffiliated citizens of various ideological and motivational backgrounds - that jointly constitute and shape "structurally underdetermined [events] characterized by high levels of uncertainty" (della Porta 2018, 7). Decisions taken during such times can have a lasting impact (see also Sewell 1996; Blee 2012), also on local civil society. The FFE protests clearly conformed to this definition; they rapidly diffused from Moscow through the country's urban spaces, mobilizing activists with an unusually broad ideological spectrum and bringing a large number of first-time protesters to the streets (e.g., Bikbov 2012; Gabowitsch 2016).

\section{The Outcome: Building Protest Organizations}

Local organization building during the high phase of diffusing protest is more likely, I argue, when the local and the national interact, i.e., when long-standing local activists $^{3}$ attempt to employ the diverse, energetic, and resourceful mobilization in their ongoing local struggles.

Whether or not protests produce local organizations, ${ }^{4}$ then, depends on whether the innovation of organization building is perceived as an opportunity to provide established local activists with advantages vis-à-vis their authorities, e.g., as a bargaining tool, for signaling societal support, or for conducting work in their ongoing projects (on perceived opportunities see Kurzman 1996; Gamson and Meyer 1996). While the particular expected use of such an organization is a function of the specifics of the local interactions and thus again depends to a great extent on the political 
environment in place, a necessary condition for local actors to perceive a diffusing protest wave as an opportunity to further their local goals is that such local goals exist in the first place. Where activists are not currently engaged in local battles when the critical juncture opens up, they will have less interest in organization building. 5

Finally, in cases when new organizations are founded, I draw on the idea of critical antecedents (Slater and Simmons 2010) as conditions that allow contingent innovation but constrain actors' palettes of available choices. Tilly's concept of repertoire fills this conceptual tool with theoretical content. I argue that even in cases where actors substantially innovate, they will do so by drawing on tactical and organizational templates available from earlier periods of contention. For instance, if the tactical repertoire is confined to conducting demonstrations, the new organization will likely not substantially expand this area of activity; if organizational repertoires include broad coalition building, a new protest SMO will likely be more inclusive than in places dominated by a close-knit group of activists; if existing organizations and activist groups function according to rigid formal or informal hierarchies, a new protest SMO will likely follow their example, and so forth.

In sum, I propose a meso-level argument that runs from (1) the impact of the structural environment on the development of activists' repertoires in a particular locality, through (2) diffusing mass protests that present a critical juncture for local organization building, to (3) the formation of new protest SMOs that depends on whether or not established activists perceive the protests as an opportunity to advance their local agendas, and on the existing repertoires that will be mirrored in the newly built organizations. The next sections test this theory, comparing four local instances of the "For Fair Elections" protests.

\section{Case Selection and Operationalization of Structural Variables}

My argument will be tested in a within-country comparison. This has the clear methodological advantage that potentially confounding variables, like the reference frames of the protests, can be controlled for by holding them constant (Snyder 2001; Giraudy, Moncada, and Snyder 2019). For the same reason, this design raises questions on the applicability of findings beyond the specific country context. The Russian case, however, displays a profound diversity of subnational political conditions. Because the argument holds that activists' repertoires are shaped to a great extent in the local political environment, this subnational variance inserts theoretically meaningful context variation and hence allows to claim more general relevance.

Based on a range of empirical indicators, recent studies have argued that the Russian regions represent different electoral authoritarian regime types. In explicit reference to Howard and Roessler's (2006) distinction, Libman (2017, 129) writes that, in the beginning of the 2010s, after ten years of authoritarianization "there still exist[ed] substantial differences in terms of regional politics, which are frequently conceptualized as those between competitive and hegemonic authoritarian regimes" (also Saikkonen 2016). Similarly, Ross and Panov identify four regional regime types that span a continuum between "hegemonic authoritarian" regional regimes, where "a dominant actor, usually a governor, is able to dominate the electoral field by controlling the nomination of candidates" and "clearlycompetitive authoritarian" regimes, where candidates of the governing party "compete in a genuine struggle for power" (Ross and Panov 2019, 370-71).

To back up this evidence with a cross-national dimension, I use data from the Varieties of Democracy project to demonstrate that Russia in the relevant time period was among the $10 \%$ of electoral authoritarian countries with the highest unevenness in the conduct of subnational elections (refer to the online appendix). Based on these findings I argue that, if the selected subnational cases maximize the within-country differences in structural conditions, these provide enough variation in political context for the argument to yield insights that are conceptually relevant beyond Russia's bordersprovided that its application is limited to electoral authoritarian regimes.

Cases are selected in a three-step process. In step one, a universe of cases is defined. I include cities that, first, displayed a minimum of $\operatorname{six}^{6}$ protest events related to the FFE-protests between the parliamentary elections on December 4, 2011, and the demonstration on Moscow's Bolotnaya square on May 6, 2012, which is widely regarded as the beginning of the protest cycle's end. Second, I exclude St. Petersburg and Moscow on the one hand, and all cities with less than 500,000 inhabitants on the other, to ensure a minimum of comparability regarding scale effects on protest. Third, only regional capitals (eighty-three at the time) make their way into the universe of cases to control for their special status in the federal administrative hierarchy (Golosov, Gushchina, and Kononenko 2016). This first step produces a set of twenty cities.

Steps two and three specify and operationalize political and economic conditions with the aim to select two cities with a favorable, and two cities with an unfavorable structural environment for protest institutionalization. Focusing on the structural conditions only, organization building during a protest wave is expected to be most likely in the favorable contexts, and least likely in the unfavorable ones. This crucial case logic increases inferential leverage for a proposed theory if a most-likely case fails to produce the outcome, or a least-likely case displays it (Levy 2008, 12-13), substantiating the causal weight of other factors (in this study: repertoires and perceived opportunities) that differ between the "passed" and the "failed" cases (see Rohlfing 2012, ch. 3). This, however, does not mean that structural conditions are irrelevant: they are a crucial, 
though mostly indirect, part of the argument since they shape established activists' repertoires and opportunities.

Step two. For selecting cases on political context conditions, I partly draw from Petrov and Titkov's (2013) widely used index that uses expert ratings to assess ten dimensions of regional democracy between 2006 and 2010 on five-point scales. Since the index covers fiveyear periods, its accuracy is naturally limited. However, in their summary of several recent findings, Lankina, Libman, and Obydenkova (2016) conclude that, despite its weaknesses, the index is a valid approximation of important structural features: its experts ratings show strong correlations with hard indicators, and several case studies (including the present one) report congruence with the index's assessments. While I do not expect the index to give precise accounts, I therefore argue that it is a useful heuristic to approximate general patterns.

A favorable political environment is conceptualized to comprise, first, relatively open political opportunity structures, defined by Kriesi et al. (1992) as consisting of a formal dimension (the functioning of political institutions such as elections) and an informal one (strategies of authorities to deal with outsiders). Where channels of bottom-up influence exist and function reliably without excessive obstruction and repression of challengers, activist groups find better working conditions, which enhances efficacy and should thus incentivize organization building. Two indicators from the Petrov/Titkov index are employed to operationalize the formal and informal openness of regional political systems: the overall quality of elections and the openness of political processes.

Second, research from Western Europe shows that, if movements are able to attract resourceful allies such as parties or individual politicians, the chance to institutionalize increases (Kriesi, Koopmans, and Duyvendak 1995). The availability of allies is operationalized negatively through the share of seats in the regional legislature controlled by the governing party United Russia (UR). More seats controlled by other forces than UR mean a higher chance that individual politicians are present who, for instance, can supply resources like finances, infrastructure, and contacts to authorities (Tarrow and Tilly 2007; on Russia see White 2015).

Finally, I assume that the presence of politically independent media that can report on the FFE protests and the organizations that emerge from them without having to fear repression are important resources for the institutionalization process, since coverage can increase efficacy of groups' actions and helps to attract new activists. The availability of favorable media coverage is operationalized through Petrov and Titkov's indicator for regional media freedom.

Step three. Since variation in economic conditions has a strong impact on political developments across the Russian regions (e.g., Gel'man et al. 2008), the third step operationalizes the availability of economic resources. For this, I rely on two variables-Gross Regional Product per capita and the number of small, non-state ${ }^{8}$ enterprises per 10,000 inhabitants - that are both taken from Rosstat, the official Russian state statistics service. The reasoning behind the former is that in richer regions, more resources may potentially be channeled to activist groups, which is essential for sustaining their activity (see, e.g., Davenport 2014). The choice of the latter variable reflects that both firm size and state ownership are strong predictors of political loyalty of employers (Frye, Reuter, and Szakonyi 2014), suggesting that small, private firms are the most likely sponsors for oppositional activity (thus making regional politics less dependent on politically controlled clientelist structures). In addition, both higher income levels and a larger non-state sector may increase the supply of available activists (Rosenfeld 2017).

To identify two most-likely and two least-likely cases, I select regions from the universe of cases that constantly feature at the top of the list on both dimensions (Perm and Yekaterinburg) and two that constantly feature at the lower end (Saratov and Rostov-na-Donu). Table 1 summarizes the structural indicators in the four cases. The online appendix demonstrates that the selected cities maximize the variation of context conditions.

\section{Data and Methods}

To facilitate triangulation in reconstructing the organization building process during the protest cycles, several data types are combined. The first data source is sixty-five semistructured interviews with participants and observers of the protest cycles (14-22 per city) mostly carried out between September and November 2017 (refer to the online appendix). Interview partners were not selected to obtain a representative sample of the protest participants, but to gain insights into the organizational processes during and after the peak of mobilization.

The second data source is a base of 1,087 local media reports, which were assembled using the Integrum database and were subsequently coded. The first component (corpus A) features 315 reports on forms, actors, and claims of protests between January and November 2011, i.e., before the outbreak of the FFE protests in December. The second component (corpus B) contains 772 reports' on the local FFE protests in all four selected cities and, where new SMOs were founded during the protests, on their activities (refer to the online appendix for detailed information on the interviews, a discussion of the selection of press sources, and coding rules). Finally, a third data source is documents like charters of new SMOs and meeting minutes that were obtained directly from activists, and social media posts (110 in total), public reports, and mobilizational materials that were accessed online (refer to $\mathrm{n} .10$ for a guide to the labeling of interview sources). ${ }^{10}$

I now present the four case studies as structured analytical narratives. The first section of each case study outlines the political context factors-political opportunities 
Table 1

Structural factors used for case selection

\begin{tabular}{|c|c|c|c|c|c|c|}
\hline \multirow[b]{2}{*}{$\begin{array}{c}\text { City } \\
\text { CASE TYPE }\end{array}$} & \multicolumn{4}{|c|}{ Political } & \multicolumn{2}{|c|}{ Economic } \\
\hline & $\begin{array}{l}\text { (1) Quality of } \\
\text { elections } \\
(2006-2010)^{a}\end{array}$ & $\begin{array}{l}\text { (2) Degree of } \\
\text { openness } \\
(2006-2010)\end{array}$ & $\begin{array}{l}\text { (3) Share of } \\
\text { UR regional } \\
\text { deputies }^{b}\end{array}$ & $\begin{array}{l}\text { (4) Media } \\
\text { freedom } \\
(2006- \\
2010)\end{array}$ & $\begin{array}{l}\text { (5) GRP } \\
\text { p.c. } \\
(2011) \text {, in } \\
\text { rubles }\end{array}$ & $\begin{array}{c}\text { (6) small, } \\
\text { non-state } \\
\text { firms per } \\
10,000 \text { inh. } \\
\text { (2011) }\end{array}$ \\
\hline $\begin{array}{l}\text { Perm } \\
\text { MOST LIKELY }\end{array}$ & 3 & 5 & $65 \%$ & 5 & 305,000 & 138 \\
\hline $\begin{array}{l}\text { Yekaterinburg } \\
\text { MOST LIKELY }\end{array}$ & 5 & 4 & $58 \%$ & 5 & 294,000 & 170 \\
\hline $\begin{array}{l}\text { Saratov } \\
\text { LEAST LIKELY }\end{array}$ & 2 & 3 & $96 \%$ & 4 & 170,000 & 93 \\
\hline $\begin{array}{l}\text { Rostov-na-Donu } \\
\text { LEAST LIKELY }\end{array}$ & 2 & 3 & $90 \%$ & 2 & 179,000 & 128 \\
\hline
\end{tabular}

and resources-that were available to activists prior to the onset of the critical juncture and then specifies the tactical and organizational repertoires (i.e., the critical antecedents) that evolved within these structural environments. The second section details the interaction of agents during the critical juncture, focusing on the decision for or against organization building, and, if new SMOs were founded, their composition, their inner form, and their activity pattern.

\section{Case Study I: Perm}

\section{Structures and Repertoires}

In the 1990s and early 2000s, political pluralism and electoral results for liberal parties were higher than the national average (S05P). Although elections in Perm were never subject to much falsification or abuse of administrative resources (S05P), in the beginning of the 2000s, a process of elite consolidation set in, during which formal political competition was gradually reduced and the regional level began to establish control over the municipal one (Kovin 2013). The gradual closure of formal opportunities was, however, partly compensated by an unusual informal openness of regional and local authorities and the continuing presence of allies in the form of independent politicians and business people with their own resource bases, who were ready to collaborate with civic activists and to develop alternative policy proposals (Kovin 2013; A08P; S03P).

Tactical and organizational repertoire. In this comparatively open and resource-rich environment, activists developed a diverse repertoire. Most action was geared towards pragmatic cooperation. Igor Averkiev, a central NGO activist, drew up a list of "rules for dealing with authorities" in 2004 (Averkiev 2004). This model entailed frequent public discussions, roundtables, and working groups that brought together NGO activists, local academics, and representatives of authorities. The application of this model resulted in several constructive interactions that even led to the adoption of bills drafted by civic actors, sometimes in collaboration with the region's Human Rights Ombudsman (Kovin 2013). But activists also knew to pressure authorities with more contentious tactics. For instance, on November 19, 2011, shortly before the FFE protests broke out, a large rally was organized by civic activists of various ideological convictions, jointly demanding Governor Oleg Chirkunov's resignation (N78). One newspaper reported that the event assembled "cultural workers, members of the intelligentsia, ... human rights activists, ... deputies and those who never heard these deputies' names" (N78). While this may be an overenthusiastic depiction, the resolution that was adopted at the event clearly shows the breadth of demands ranging from an end to Chirkunov's controversial cultural policy ${ }^{11}$ over housing problems and welfare claims to criticism of excessive regional influence on the municipal level (Nesekretno 2011), proving a successful instance of frame bridging that culminated in a shared anti-gubernatorial stance.

Organized activism was thus frequently characterized by broad coalitions of various NGOs, individual parliamentary deputies, and single activists. At the center usually stood four human rights groups that had formed in the 1990s and had gained a strong local reputation (P01P; S02P). These coalitions sometimes endured over months or even years, as was the case in a campaign against the planned abolishment of direct mayoral elections in 20092010 (A08P; P02P; S05P) and were supported by and connected to a significant share of the urban populace. 


\section{Organization Building during the Protest Cycle}

In Perm, just like in the following cases, none of the described groups, coalitions, or individuals stood at the outset of the local protest cycle. Instead, the protests began in online discussions on the Facebook equivalent VKontakte (VK), where people received news about the electoral falsifications and the beginning protests in Moscow and called for action in their hometown. Two young activists with some experience found their way into these discussions and helped to set up the first improvised protest action, followed by another, larger event a few days later (A04P; A10P).

Founding a new protest SMO. The long-standing civil society activists at first perceived the erupting protests in Moscow as "fashion" (P02P), "not our protest" (A08P), "unimportant" (S05P), something detached from their local concerns-especially since electoral falsifications in Perm had not been extensive. But when the protests diffused to Perm and gained momentum, the veterans seized the initiative from the newcomers, called a meeting in a downtown restaurant and, together with several activists from the VK group, laid the foundation for a new SMO-the Council of 24th December (named after the day on which it came into existence).

I argue that the main reason for investing in organization building was that the established activists saw this emerging movement as a chance to propel their longstanding campaign against the governor. In the discussions in the new organization, the digitally mobilized first-time activists focused on the national agenda, demanding free elections and more honesty in politics, while the veteran activists pushed their regional agenda that included Chirkunov's resignation (P01P; A09P; A10P). A newcomer recalled that "at the first stage there was a conflict: 'Who are we up against: [Governor] Chirkunov or [Prime Minister] Putin?' For the youth, it was important to be against Putin, and for the civic activists and politicians to be against Chirkunov. Some of [the latter] joined just because of that" (P01P). Another newcomer confirmed that "they [the veterans] had an exclusively local agenda. On all protests they [agitated for the resignation of] Chirkunov. And we: 'we need to change the country, why are you so fixed on him?"” (A09P).

The change of agenda as a result of the established activists' increased engagement is further corroborated when comparing the list of demands of the demonstrations of December 11 and 24 respectively; the latter included Chirkunov's resignation (N908), while the former, where established activists played almost no role, did not (SM81). Moreover, brokered by the Human Rights Ombudsman, the Council organized a closed-door meeting with Chirkunov in January 2012, where they pressed different demands concerning regional and local elections, referenda, and the protests' resolutions (P01P; A08P; S04P). The available evidence therefore strongly suggests that it was the perceived opportunity to increase their standing and their bargaining power vis-à-vis the authorities that brought veteran activists to engage in the protests and to invest in organization building.

Structuring the new SMO. The established activists understood that the organizers of the first events needed to be included in any new initiative, because they commanded the mobilizational resources through the VK group (A04P). So, the Council was divided into three factions of seven members each: (1) long-standing civic activists, (2) politicians, and (3) so-called "online activists" (S03P; ID01P), with the latter faction being composed largely of young people without prior connections to the members of faction (1) and (2). The Council's internal structure was designed to facilitate understanding and to create balance between the camps: Decisions were to be taken by simple majority (ID04P), and two Council members, one veteran and one newcomer, were made director and press secretary, paid by funds provided by two member politicians, as a "measure to keep these different people together for longer" (S05P).

These measures usually allowed consensus across the veteran/newcomer divide (A04P; A09P), although the structural majority that veterans had formed by making up two of the three factions meant that newcomers could not prevent the local agenda from being introduced, which frustrated two of them, leading to their withdrawal from the political activist scene in subsequent months (A10S).

Although the new SMO was an innovation, actors' organizational repertoire clearly shines through: At the core of the Council stood a group of activists and politicians with diverse organizational affiliations and political outlooks but with overlapping local agendas, who knew each other from the numerous previous coalitions. Likewise, the Council's activities closely resembled the existing, diverse tactical repertoire (refer to figure 1). Its activities included contentious practices like the organization of protests and electoral monitoring, but also continued the cooperative traditions, manifesting in several debates and roundtables and the meeting with governor Chirkunov. In sum, therefore, I argue that the outcome in the first case was caused by an interplay of a perceived opportunity and existing templates of action and organization available from pre-FFE times.

\section{Case Study II: Yekaterinburg}

\section{Structures and Repertoires}

Throughout its post-Soviet history, politics in the Ural's capital and the Sverdlovsk region had been characterized by conflict between the local and the regional layer of administration (Il'chenko 2015; A05Y). In contrast to other regional centers, this basic conflict survived the construction of the "power vertical" by President Putin 


\section{Figure 1 \\ New protest SMOs and their main reported activities in Perm and Saratov between December 2011 and March 2012}

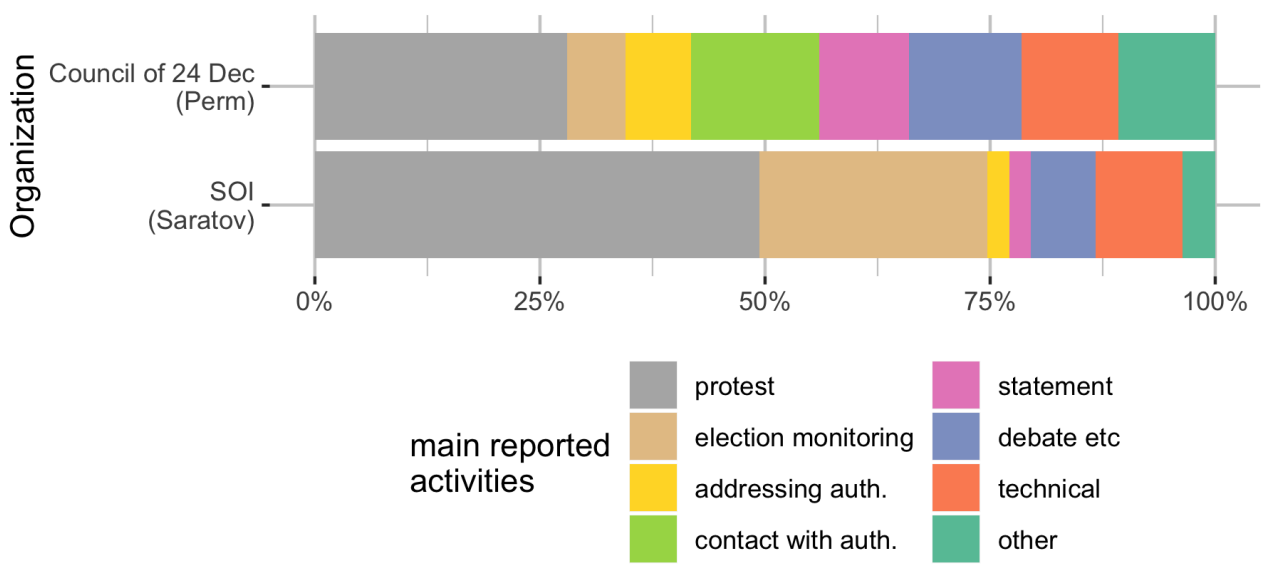

Notes: "Technical" refers to media mentions about the composition of the groups, their founding and dissolution. Total media mentions of activities: 232 in Perm, 83 in Saratov.

Source: Newspaper reports (corpus B).

in the 2000s. In addition, strong economic development through the 2000s contributed not only to the emergence of a relatively well-off and educated urban middle class, but also to the establishment of a group of independent business people with vested political interests (A05Y), who aligned with various political actors (Il'chenko 2015). Despite the authoritarianization emanating from the federal center (Kynev 2014, 586-92), the continuing conflict provided for higher degrees of pluralism and more public contestation than in other Russian regions, which was both evident in and perpetuated by a diverse local media landscape (J01Y). In this relatively open pluralist context where dissenting actors did not have to fear substantial repression, tactical and organizational repertoires developed that resembled Perm's in critical ways.

Tactical and organizational repertoire. The emergence of a diverse tactical repertoire, ranging from relatively frequent and large demonstrations to the organized use of official democratic instruments like public hearings and discussions, was accelerated by the entering of Leonid Volkov into local politics. A young mathematician and programmer, Volkov became popular among the city's emerging middle class through his blog, begun in 2007. In 2009, without any connections to politics (A03Y), he won a seat in the local parliament. Around the same time, he became the head of the local chapters of the electoral observer organization Golos and the liberal coalition Solidarnost ${ }^{12}$ (A02Y; A05Y). In 2010 and 2011, he led three campaigns that all involved large rallies - one against the construction of a cathedral on a central square, ${ }^{13}$ one for the preservation of direct mayoral elections (J02Y; A03Y), and one for granting him access to the regional elections of December 2011, from which he had been excluded on dubious grounds (Ekho Moskvy 2011). As Lankina’s (2018) data set suggests, protest had been frequent before, but it had been dominated by social and economic concerns (P03Y). These new campaigns, by contrast, were carried out in defense of moral and political values, bringing a new group of people to the streets and into activism: highly educated, sometimes even affluent urbanites (Il'chenko 2015).

As in Perm, organized activism before the FFE protests was often carried out in broad coalitions that involved actors and groups with different ideological programs but with overlapping local agendas and with firm connections to the wider citizenry. The campaign for retaining mayoral elections, for instance, was coordinated by a group called the "Committee for the Right to Vote" (CRV) composed of several liberal activists, a respected local scholar, a journalist, and a deputy of the Communist Party (CPRF) (P01Y; J02Y). In contrast to Perm, however, there was informal but clear personal leadership, as Volkov was always in the center of mobilization and organization (e.g., P01Y; A05Y; A08Y).

To the extent that Volkov established himself as the center of liberal activism, this left an imprint on the dominant organizational practices. Using digital communication tools, he developed a style of ad hoc coordination"decisions without meetings," as one aide put it (A08Y) without fixed roles, let alone formal organizations: "Everything was communicated on the fly" (A03Y).

\section{Ad hoc Coordination during the Protest Cycle}

The protests started out similarly to the other studied cases. A VKontakte group appeared "out of nowhere" 
(A08Y), where people unknown to the established activists coordinated a flash mob and a spontaneous march to the building of the city administration (P03Y). But after the first actions, a loose organizational committee began to form around Leonid Volkov. It included several members of the CRV (A01Y; A03Y), two young activists from the Communist Party (who used their connections to the party's follower base and its financial resources for mobilization), an activist of the social liberal Yabloko party, and several people from Volkov's orbit (P01P; P03P). These established activists worked together with numerous newcomers, registering the planned protest events with authorities and coordinating the online and offline mobilization (P03Y; A06Y).

Coordination during the protests was ad hoc, inclusive and noncommittal. In fact, "anyone could join" (A03Y). The working atmosphere inside the committee was described as good, there was "no internal competition" between political camps (A01Y), and it functioned without fixed roles: at the meetings in Volkov's deputy reception room people simply took on tasks themselves and effected them (A09Y).

In crucial difference to Perm, this informal coordination never gave way to a phase of organization building, so that the protests petered out in parallel to the national protest wave without leaving behind any new SMOs. What accounts for this non-outcome is, I argue, that the group around Volkov had no ongoing projects that would have benefitted from institutionalizing the protests into a permanently active collective actor: The local battles of 2010 and 2011 had been fought and won or lost: The church was not built, the mayoral elections were retained (albeit with a mayor who was stripped of most of his powers), and Volkov was excluded from the regional ballot without a chance to be reinstated. At this moment, therefore, the central activists were not waging campaigns into which they could usefully channel the FFE mobilization. In addition, even if the protests had appeared as an opportunity to further a local cause, the organizational repertoire of ad hoc coordination established since the late 2010s was not conducive to formalization. Both of these factors - the absence of a perceived opportunity and a specific organizational repertoire-made it highly unlikely for established actors to invest in organization building at the particular time when the critical juncture opened up. As a consequence, the FFE protest cycle did not trigger a break from the established patterns of activism. ${ }^{14}$

\section{Case Study III: Saratov}

\section{Structures and Repertoires}

As the case selection strategy implies, pre-FFE Saratov presents a stark contrast to the two cases just described. Elections were strongly controlled, with a long history of falsifications and backroom deals instead of open contestation (A02S). Although broad and open repression was infrequent, potential conflict between levels of government had been prevented from fueling public displays of political discontent, while political challengers with independent resource bases were absent, and any formally organized opposition was marginalized with the help of courts, tax authorities, and other instruments (Gel'man et al. 2008). Moreover, even formally independent media operated under the permanent threat of harassment or the cutting of informal payments from authorities (A10S; A12S).

Tactical and organizational repertoire. Given the closed opportunity structures and the lack of allies and contacts to authorities, the repertoire of local agents was - in contrast to the previous two cases-largely confined to symbolic contention like protest demonstrations. Even when conducted by several parties, these rallies hardly gathered more than 200 participants (N197; N207; N227), suggesting that oppositional political society was largely disconnected from the broader urban public.

Consequently, large civic coalitions of the Perm and Yekaterinburg type were nowhere in sight. Instead, protest in Saratov in the late 2000s was often carried out with the support or within the campaigns of opposition parties (A14S), whose predominance on this field attests to the relative organizational weakness of other civic actors ${ }^{15}$ and suggests that in the absence of other channels of influence, parties resorted to street protests as a relatively costeffective way to raise awareness. The press report database (corpus A) confirms the interview accounts: in 2011, more than half of the 43 protest events between January and November 2011 were at least co-organized by a political party (see figure A1 in the online appendix), which is about twice the share of Perm and Rostov and four times the share of Yekaterinburg.

After municipal elections in March 2011, four partiesthe CPRF, Yabloko, the social democratic JR and the nationalist LDPR - officially formed a local alliance, whose main intention was to achieve the revocation of the municipal election results (N199) and who cooperated in the organization of small protest rallies on March 18 (N197), April 2 (N207), and May 19 (N227). Shortly before the FFE protests began, therefore, the organizational repertoire was characterized by cooperation between a limited set of decidedly political actors who focused their attention on the electoral process rather than particular policy projects or broader local issues.

\section{Organization Building during the Protest Cycle}

As in the other cities, a first colorful rally was organized through VKontakte and held on December 10. During the following month, a critical organizational innovation was undertaken that differed from Perm's Council in essential ways. 
Founding a new protest SMO. Towards the end of December, a heterogeneous committee formed to organize the following rallies. Recruited from this committee, a smaller circle of party and political NGO activists got together to establish a new SMO, the Saratov Association of Voters (SOI in Russian). This body was supposed to unite opposition-minded people from various ideological strands around electoral control, since all opposition parties had suffered from falsifications at the ballot box (A09S; N1364) and sought to gain votes and secure proper vote counting to increase their "political maneuver space" (A09S). In this effort, the local party leader who proposed the idea specifically linked it to the party alliance formed earlier that year. In a VK post, he wrote that "in terms of its public and practical content, SOI is a successor to the inter-party committee 'Saratov-fair elections!' (LDPR, CPRF, 'Just Russia', 'Yabloko'), established in the run-up to the elections to the Saratov City Duma in March 2011, as well as the protest movement of Saratov's citizens" (SM110).

Again, what gave the impulse for organization building during the protests' early phase was the perceived opportunity of local agents- this time, mostly party activiststo employ the emerging movement in their struggle to improve the local electoral process.

Structuring the new SMO. The way this new SMO was set up resembled the tactical and organizational repertoires available to the involved activists in at least two ways. The first concerned its composition. In inviting potential members for setting up the organization, its founders excluded several participants of the protests' first loose organizational committee who were not members of established political organizations (A09S; A14S), reducing the circle to activists who "knew each other from before" (A06S). The focus both in the participants' recollections (A01S; A06S; A13S) and in the public record of this meeting (Kommersant 2012) was clearly on parties, while unaffiliated activists were represented only by the two administrators of the VK group (A11S; A14S). The latter found their position to be too marginal to meaningfully contribute and left the project frustratedly, complaining in the VK group that "it is necessary to say that such a balance of forces [in SOI] reflects society's real moods even less than the current State Duma [the national parliament]? We fully understand the natural aspiration of our political parties to crush the civil movement, but we reserve the right to expose these aspirations" (SM21).

The focus on a specific subset of agents in forming the new group that-at least in the initial stages—excluded most of the newcomers without clear political affiliations reflects the organizational patterns that dominated local activism before the outbreak of the FFE protests.

The second way in which these patterns revealed themselves concerns SOI's internal structure. One of the few newcomers who had been invited to the founding meeting but left in frustration, observed about the internal proceedings that "SOI consisted of [the liberal party] PARNAS, Yabloko, the Prokhorov platform ${ }^{16}$; and there were also the communists ... Everyone tried to hold round tables ... where decisions and memoranda were made. All the time they were voting, accepting something, as parties all like to do" (A11S).

This clearly shows this activist's disappointment, but the description of the formalistic, bureaucratic process seems accurate, as accounts from involved activists confirm (A02S; A04S; A09S). Indeed, establishing fixed roles and procedures was part of the founder's strategy to create an organization that would effectively conduct electoral monitoring in the upcoming presidential elections of March 2012, the declared main goal of the new SMO (A09S). He was aware that there were potential drawbacks, but set clear priorities: "the structure may seem bureaucratic, but it is a protection mechanism .... . There is a trade-off: on the one hand dry, uninteresting, bureaucratic [work], and on the other hand-if there are no positions prescribed on paper, there is no organization" (A09S).

Internal organizing practices of the dominating parties thus not simply spilt over into the new SMO but were consciously introduced. The effect is clearly visible in SOI's activity pattern over the high phase of the protest cycle, which is focused on protest and electoral monitoring much less diverse than in Perm (see figure 1).

\section{Case Study IV: Rostov-na-Donu}

\section{Structures and Repertoires}

Over the post-Soviet period, Rostov's political structures, both formally and informally, were closed to outside influence. Opposition parties were hardly represented in the political institutions (the CPRF being a partial exception) and were no reliable allies for oppositional political or civic projects (McFaul and Petrov 1998; Kynev 2014). Moreover, allies in the form of independent media and resourceful independent political challengers or businesspeople were virtually non-existent (S01R), since the authorities had set clear examples by severely punishing independent business owners' political activity several times in the 2000s (S01R; A07R). Repression against even small acts of political dissent was on a comparatively high level, as evident in the frequent mentioning of arrests and threats in interviews compared to the other cases.

Tactical and organizational repertoire. In this environment, any form of activism was precarious and marginal. To be sure, Rostov was not devoid of protest. There was mobilization in the coal-mining sector and on environmental issues in the 1990s, while Lankina's (2018) data point to several comparatively large protest rallies in the second half of the 2000s, e.g., by veterans of the Chernobyl catastrophe and nationalist youth. However, these events hardly produced any stable activist groups. The 
only source of permanent contention was a small group of persistent, "non-systemic" oppositionists (i.e., not belonging to a parliamentary opposition party) who tirelessly staged small protest pickets across the city, always risking arrest and obstruction from authorities. Their tactical repertoire was strictly limited to protest, and their pickets attracted even fewer participants than party protest in Saratov-usually about 30-50 (A04R; P01R). These events were exclusively political in nature and usually targeted national developments rather than local issues.

This small activist group displayed a very heterogeneous ideological background, with activists identifying with liberal groups like Solidarnost' or the United Civic Front, with the Left Front, or with Other Russia - the successor organization of the National Bolshevik Party that had been banned in 2007, whose ideology blended fascism and state socialism (A02R; A04R; A10R; A11R). Members of this informal alliance bridged their political differences by limiting their joint actions to the lowest common denominator of criticizing the national authorities and demanding freedom of assembly. However, this cross-ideological group of battle-hardened activists lacked stable working connections to opposition politics (to the extent that these existed), to actors of social protests, and to the urban population at large. Coalitions of the Perm and Yekaterinburg type were thus, again, not part of the organizational repertoire.

\section{Ad hoc Coordination during the Protest Cycle}

The FFE protest cycle in Rostov began with several events that were organized online in an ad hoc fashion and conducted by people unknown to the city's long-standing protest group. On December 6, a rally of mostly young protesters, holding up blank pieces of paper, was dispersed by riot police with forty-nine people arrested (N166). A second rally was held on December 10-and still one of the major organizers of oppositional protest in Rostov claimed to have no knowledge of those behind the event (A02R). It was only in preparation for the cycle's major rally on December 24 that the established activists got together with some of the newly mobilized youth to jointly organize the protests. But the central activists still had no full understanding of the protests' new anonymous youthful base (A04R; A11R). Several interviewees claimed that mobilization to the demonstrations often happened without direct connection to the organizational committee (A04R; A11R; A12R). Spontaneous mobilization overall lasted longer and was less successfully integrated than in the other cases, even compared to the loose organizational committee of Yekaterinburg.

As in all other cases, the established activists hoped that the protests would swell the ranks of their small political organizations, like Solidarnost' or the Left Front (A02R), but-in contrast to Perm and Saratov, and much like in
Yekaterinburg - they made no attempts at organization building. Again, I argue that the primary explanation of this non-outcome is to be found in established activists' lack of perceived opportunities and their existing repertoires. In contrast to Perm and Saratov, activists had little grounding in local issues and conflicts. This is further illustrated by the fact that they did not introduce local demands into the demonstrations, instead focusing exclusively on the national agenda (A02R; A11R), critiquing the federal elections and prime minister Vladimir Putin. Had activists been more engaged on the local level (which was, however, very difficult given the closed local environment and the ideological heterogeneity of the group), this could have provided them with a stronger impulse towards stabilizing the movement and harnessing it for further battles by channeling it into a new organization. Moreover, the tactical repertoire that was limited to protest pickets did not provide templates for other action, while the habit of organizing in a close-knit circle of committed activists that was fostered by the comparatively high level of repression made the group quite resilient but did not offer scripts for dealing with a sudden influx of new activists.

As a consequence, the protests quickly petered out after the presidential elections in early March 2012, while the composition of remaining small protest gradually came to resemble the old guard of pre-FFE political activism (A02R; A04R; A11R). ${ }^{17}$ Table 2 summarizes the findings of the four case studies and places them in the 3-step analytical model.

\section{Discussion and Conclusion}

When does diffusing protest in an electoral authoritarian regime produce new local activist organizations? I have argued that organization building in these situations is more likely when the national and the local interact, i.e., when long-standing activists are willing and able to use the protests for their ongoing local struggles. Whether and how they do this depends, in turn, on their accumulated experience of interactions with authorities in their particular political environment.

More specifically, I have proposed three interrelated causal factors-(1) structures, (2) repertoires, and (3) perceived opportunities - that jointly account for the emergence and the form of new local SMOs. As the crucial case design has demonstrated, (1) local opportunity structures, available allies, and resources do not directly predict organization building during a wave of mass protests. Instead, these structural facilitators and constraints contribute over years (and sometimes decades) to the development of (2) distinct sets of repertoires that activists use in their interactions with authorities. When a critical juncture in the form of diffusing mass protests opens up, local organization building is more likely ${ }^{18}$ in case these established activists (3) perceive the protests as an 


\section{Table 2}

Organizational outcomes of diffusing protest

\begin{tabular}{|c|c|c|c|c|c|}
\hline \multirow[b]{2}{*}{$\begin{array}{c}\text { City } \\
\text { CONTEXT TYPE a }\end{array}$} & \multirow{2}{*}{$\begin{array}{c}\text { Critical } \\
\text { Antecedents } \\
\\
\text { Repertoires: } \\
\text { Tactics and } \\
\text { organizational } \\
\text { forms }\end{array}$} & \multicolumn{2}{|c|}{ Critical Juncture } & \multicolumn{2}{|c|}{ Outcome: Organization Building } \\
\hline & & $\begin{array}{c}\text { First FFE } \\
\text { mobilization }\end{array}$ & $\begin{array}{l}\text { Perceived } \\
\text { opportunity of } \\
\text { organization } \\
\text { building }\end{array}$ & $\begin{array}{c}\text { Interactions } \\
\text { of veterans } \\
\text { and } \\
\text { newcomers }\end{array}$ & $\begin{array}{c}\text { Structure of new } \\
\text { SMO } \\
\text { (composition, } \\
\text { activity pattern, } \\
\text { inner form) }\end{array}$ \\
\hline $\begin{array}{l}\text { Perm } \\
\text { FAVORABLE }\end{array}$ & $\begin{array}{l}\text { Diverse forms of } \\
\text { activism, open } \\
\text { coalitions, broad } \\
\text { set of actors }\end{array}$ & & yes & $\begin{array}{l}\text { Founding } \\
\text { new SMO }\end{array}$ & $\begin{array}{l}\text { Inclusive } \\
\text { (coalition); } \\
\text { diverse activity; } \\
\text { unbureaucratic }\end{array}$ \\
\hline $\begin{array}{l}\text { Yekaterinburg } \\
\text { FAVORABLE }\end{array}$ & $\begin{array}{l}\text { Diverse forms of } \\
\text { activism, open } \\
\text { coalitions, broad } \\
\text { set of actors }\end{array}$ & $\begin{array}{l}\text { Online; ad hoc; } \\
\text { unconnected }\end{array}$ & no & $\begin{array}{l}\text { Operating } \\
\text { with loose } \\
\text { networks }\end{array}$ & \\
\hline $\begin{array}{l}\text { Saratov } \\
\text { UNFAVORABLE }\end{array}$ & $\begin{array}{l}\text { Concentrated on } \\
\text { protest, } \\
\text { narrow set of } \\
\text { actors }\end{array}$ & $\begin{array}{l}\text { to established } \\
\text { centers of } \\
\text { activism }\end{array}$ & yes & $\begin{array}{l}\text { Founding } \\
\text { new SMO }\end{array}$ & $\begin{array}{l}\text { Exclusive (party- } \\
\text { based); } \\
\text { concentrated } \\
\text { activity; } \\
\text { bureaucratic }\end{array}$ \\
\hline $\begin{array}{l}\text { Rostov } \\
\text { UNFAVORABLE }\end{array}$ & $\begin{array}{l}\text { Concentrated on } \\
\text { protest, } \\
\text { narrow set of } \\
\text { actors }\end{array}$ & & no & $\begin{array}{l}\text { Operating } \\
\text { with loose } \\
\text { networks }\end{array}$ & \\
\hline
\end{tabular}

opportunity to advance their local agendas. In that process of forming new SMOs, established activist then tend to fall back on the tactical and organizational repertoires developed in earlier periods of contention.

Leveraging Russia's exceptional subnational variability, the case selection has approximated the difference in local political conditions between competitive and hegemonic authoritarian regimes, providing enough contextual variance for the argument to travel. At the same time, the study has controlled for city size, administrative status, the reference frames of the protest cycle, and the national political environment. Holding these factors constant provided a methodological advantage for the case comparisons (Snyder 2001), but a next step should take the theory to a test that includes variation on conditions that the present study has bracketed out. Before that, however, its scope conditions need to be properly defined.

The case selection does not warrant extrapolation beyond the limits of electoral authoritarianism. This concerns more open and democratic contexts, but also fully repressive ones. Where resources abound and the political structures are receptive to various sorts of civic input so that the local activist scene is large and endowed with a multitude of tactical and organizational templates, these might cancel each other out or produce conflict rather than dominating the organizational decisions as they did in the studied cases. But repression also needs to stay below a threshold that precludes the public formation of openly dissenting activist groups. Any applications of the argument must therefore be kept within the confines of electoral authoritarianism (classically, Schedler 2010).

If these boundaries are respected, the study can make a contribution to theory in three distinct ways. First, offering a concrete application of the recent suggestion to understand protest cycles as critical junctures (della Porta 2018), it fuses structure and agency (Blee 2012,38) in one explanatory model that can be utilized in other contexts and even filled with other variables. Second, it highlights the importance of varieties of authoritarianism (e.g., Howard and Roessler 2006) for social movement theory, which still often operates with a binary distinction between democracy and autocracy. In both types of contexts, the findings suggest, protests can produce new SMOs. However, to the extent that closed, resource-poor, and more repressive environments induce experienced activists to develop narrower and more stringent tactical and organizational templates, the founding processes of SMOs are likely to be characterized by substantially different input across contexts. Finally, the study illuminates within-country differences in the functioning of 
hybrid regimes and demonstrates how local political conditions indirectly shape protest trajectories and affect opposition action. It thereby supports the recent move in comparative politics to give more systematic attention to the subnational level (Giraudy, Moncada, and Snyder 2019).

I propose the following questions to be addressed in future research. First, understanding that organization building in protest waves is especially relevant under RMT's assumption that organizations can keep a movement going after the demobilization of protest (Staggenborg 1998). In the studied cases, there is tentative evidence that the early organization building observed in Perm and Saratov indeed stimulated an abeyance process that was absent in the other two cities. For instance, when the liberal opposition politician Aleksey Navalny conducted his country-wide presidential campaign in 20172018, in Perm his campaign office was operated by several activists who had begun their activism in connection to Perm's Council (Dollbaum 2020). In Saratov, an indirect result of the early organization building was the emergence of a new local media source that developed into a new center of liberal activism which supplied Navalny's activists with judicial help and media coverage. It therefore appears that early organization building can be an important ingredient if protest waves are to incrementally contribute to civil society growth. Further studies should substantiate these findings and systematically compare them to other institutionalization processes.

Second, the findings recall the old oligarchization dilemma postulating that effectiveness comes at the cost of hierarchy (Rucht 1999). From the perspective of organization building, the protests were most successful when veterans seized the initiative, thereby provoking resistance and frustration of some central newcomers (especially in Saratov), while the less structured interactions in Yekaterinburg and Rostov were more harmonious but less productive. Further research could investigate under which conditions this dilemma can be avoided or mitigated by conscious design of rules for membership and decisionmaking (see, e.g., Sutherland, Land, and Böhm 2014). While such strategies may help activists to overcome conflict and create synergies, this study suggests that repertoires from earlier periods of contention will continue to play a major role.

\section{Supplementary Materials}

Appendix 1. Additional Figures

Appendix 2. Extrapolation of Results beyond the Russian Case

Appendix 3. Interview Sampling Frame

Appendix 4. Gathering and Coding of Newspaper Data

To view supplementary material for this article, please visit http://doi.org/10.1017/S1537592720002443.

\section{Notes}

1 The other four of Ahrne and Brunsson's five elements of "partial organizing" are procedural rules, hierarchy, monitoring of members' performance and compliance, and sanctions; Ahrne and Brunsson 2011, 85-87.

2 These two facets often empirically overlap. They are kept apart here to highlight the specific importance of organizational forms for later organizational choices.

3 Established (or "veteran") activists are defined here as individuals who are familiar with and part of the local activist scene, be it through membership in political or social activist groups and organizations or through a history of protest participation and organization.

4 An organization is conceived to be local when it is founded on the initiative of local activists. A branch of a centrally conducted campaign would therefore not be considered local, even if it was run by activists from that particular city.

5 Established activists may pursue other goals too, like attracting new members into their existing organizations. I assume, however, that these two goals may be pursued in parallel.

6 This threshold ensures that in all cases there was some continuity of mobilization. The number of six is arbitrary, but the list of potential cases is fairly robust to increasing or decreasing the threshold by one $(+/-$ one case).

7 This part of the index captures "media that are independent of the administration" and assesses the "pressure on media from authorities"; Petrov and Titkov 2013, 6. It does not include regional internet penetration. Measured as the percentage of adults who use the internet, this factor was very similar across all four cases (between 36\% in Sverdlovsk and 37.4\% in Rostov, with the median being 37.3\%); see Yevtyushkin, Khokhlov, and Shaposhnik 2012.

8 Firms are counted that have not more than $25 \%$ state ownership; see ICSID, n.d.

9 The covered time period varied by case: In all cities, the protests were over by fall 2012, but in Saratov, the organization built during the protests continued to be reported on through 2014.

10 Sources are marked as follows: Each source item has a number and a character identifier to mark the source type: Interviews are marked with "A/J/P/S" (activist, journalist, politician, or scholar), press reports with "N" (newspaper), social media documents with "SM", internal documents with "ID”. Interviews and internal documents in addition have a letter for the respective city where they were taken, e.g., "A01P" is activist number 1 from Perm. Refer to online appendix 3 for a full list of interviews.

11 Already on June 30, 2011, several hundred members of Perm's renowned cultural institutions had protested 
against governor Oleg Chirkunov's cultural policy, which had also drawn severe criticism from the NGO activists and oppositional politicians; S02P, P01P, A08P, N43.

12 The organization was founded in 2008 by liberal opposition politicians. It held its first protest event in early 2009 and helped to coordinate electoral monitoring before the 2011 elections.

13 This campaign from 2010 should not be confused with the more well-known protests against the construction of a cathedral in 2019.

14 An alternative explanation for this non-outcome concerns the centrality of Leonid Volkov. He shifted his focus to the national level in 2012 which could explain that local organization building lost one of its strongest potential drivers. However, Volkov remained in Yekaterinburg through the spring of 2012, so that nothing suggests that he withdrew during a phase in which a protest organization would otherwise have been built.

15 There was, however, a small but persistent environmental scene and also a relatively well-developed nationalist sector. The latter was integrated with the local liberal organizations to an unusual degree, manifested, e.g., in joint demonstrations; A06S, $\mathrm{N} 236, \mathrm{~N} 240$.

16 SOI included a group of activists affiliated with the business magnate Mikhail Prokhorov who ran in the presidential elections of March 2012 as a liberal candidate.

17 The protests did leave behind a loose group of newcomers engaging in electoral monitoring under the label of "Citizen Observer" adapted from a Moscow group. However, this group was not a form of organization building as defined earlier. It was, moreover, highly focused on its informal leader and broke apart as soon as she withdrew from activism; (A01R, A09R, S01R.

18 The probabilistic language here is crucial, as I do not claim that established activists and their repertoires are the only pathway to new organizations.

\section{References}

Ahrne, Göran, and Nils Brunsson. 2011. "Organization

Outside Organizations: The Significance of Partial

Organization." Organization 18(1): 83-104.

Averkiev, Igor. 2004. "'Permskiye Pravila Povedeniya'

[Perm's Rules of Conduct].” 2004. Retrieved

December 13, 2019 (http://www.prpc.ru/ averkiev/041110.shtml).

Beissinger, Mark R. 2013. "The Semblance of Democratic Revolution: Coalitions in Ukraine's Orange Revolution." American Political Science Review 107(3): 574-92.
Bikbov, Alexander. 2012. "The Methodology of Studying 'Spontaneous' Street Activism (Russian Protest and Street Camps, December 2011-July 2012). Summary." Laboratorium. Zhurnal Sotsial'nykh Issledovaniy 2:275-84.

Blee, Kathleen M. 2012. Democracy in the Making: How Activist Groups Form. Oxford Studies in Culture and Politics. New York: Oxford University Press.

Bunce, Valerie J., and Sharon L. Wolchik. 2010. "Defeating Dictators: Electoral Change and Stability in Competitive Authoritarian Regimes." World Politics 62(1): 43-86.

Capoccia, Giovanni. 2015. "Critical Junctures and Institutional Change." In Advances in ComparativeHistorical Analysis, ed. James Mahoney and Kathleen Thelen, 147-79. New York: Cambridge University Press.

Clemens, Elisabeth S. 1997. The People's Lobby: Organizational Innovation and the Rise of Interest Group Politics in the United States, 1890-1925. Chicago: University of Chicago Press.

Davenport, Christian. 2014. How Social Movements Die: Repression and Demobilization of the Republic of New Africa. New York: Cambridge University Press.

della Porta, Donatella. 2018. "Protests as Critical Junctures: Some Reflections towards a Momentous Approach to Social Movements." Social Movement Studies, December, 1-20.

Dollbaum, Jan Matti. 2020. "Protest Trajectories in Electoral Authoritarianism: From Russia’s 'For Fair Elections' Movement to Alexei Navalny's Presidential Campaign." Post-Soviet Affairs 36(1): 192-210.

Earl, Jennifer. 2015. "The Future of Social Movement Organizations: The Waning Dominance of SMOs Online." American Behavioral Scientist 59(1): 35-52.

Ekho Moskvy. 2011. "Miting v Yekaterinburge: Volkov, Naval'ny, i drugie [Rally in Yekaterinburg: Volkov, Navalny, and others]." Ekho Moskvy (blog). November 26, 2011. Retrieved December 11, 2019. (https:// echo.msk.ru/blog/soobshestvo/833856-echo/).

Fligstein, Neil, and Doug McAdam. 2011. "Toward a General Theory of Strategic Action Fields." Sociological Theory 29(1): 1-26.

Fox, Jonathan. 1996. "How Does Civil Society Thicken? The Political Construction of Social Capital in Rural Mexico." World Development 24(6): 1089-103.

Frye, Timothy, Ora John Reuter, and David Szakonyi. 2014. "Political Machines at Work: Voter Mobilization and Electoral Subversion in the Workplace." World Politics 66(2): 195-228.

Gabowitsch, Mischa. 2016. Protest in Putin's Russia. Cambridge: Polity Press.

Gamson, William A., and David S. Meyer. 1996. "Framing Political Opportunity." In Comparative 
Perspectives on Social Movements, ed. Doug McAdam, John D. McCarthy, and Mayer N. Zald, 275-90. Cambridge: Cambridge University Press.

Gel'man, Vladimir. 2015. "The Politics of Fear." Russian Politics \& Law 53(5-6): 6-26.

Gel'man, Vladimir, Sergei Ryzhenkov, Elena Belokurova, and Nadezhda Borisova, eds. 2008. Reforma Mestnoy Vlasti v Gorodakh Rossii, 1991-2006. Sankt-Peterburg: Norma.

Giraudy, Agustina, Eduardo Moncada, and Richard Snyder. 2019. "Subnational Research in Comparative Politics: Substantive, Theoretical, and Methodological Contributions." In Inside Countries, ed. Agustina Giraudy, Eduardo Moncada, and Richard Snyder, 2-54. Cambridge: Cambridge University Press.

Golosov, Grigorii V., Kristina Gushchina, and Pavel Kononenko. 2016. "Russia's Local Government in the Process of Authoritarian Regime Transformation: Incentives for the Survival of Local Democracy." Local Government Studies 42(4): 507-26.

Greene, Samuel A. 2013. "Beyond Bolotnaia: Bridging Old and New in Russia's Election Protest Movement." Problems of Post-Communism 60(2): 40-52.

Howard, Marc Morjé, and Philip G. Roessler. 2006. "Liberalizing Electoral Outcomes in Competitive Authoritarian Regimes." American Journal of Political Science 50(2): 365-81.

Il'chenko, Mikhail. 2015. "The Protest Movement in Yekaterinburg." In Systemic and Non-Systemic Opposition in the Russian Federation: Civil Society Awakens? Ed. Cameron Ross, 199-217. New York: Routledge.

ICSID. N.d. Database on economic and political indicators for the Russian regions in 2000-2011, created by the International Center for the Study of Institutions and Development at the Higher School of Economics, Moscow. Retrieved April 21, 2020. (https://iims.hse.ru/en/csid/databases).

Kommersant. 2012. "Vybory Podgotovyat Iz SOI [Elections Are Prepared by SOI]." Kommersant, January 20. Retrieved December 11, 2019. (https:// www.kommersant.ru/doc/1854480).

Kovin, Vitaliy S. 2013. "Stilistika grazhdanskoy zhizni Permi [Style of civic life in Perm].” In Perm' kak stil': prezentatsii permskoy gorodskoy identichnosti [Perm as style: persentations of Perm's urban identity], ed. E. G. Tregubova, 175-99. Perm: PGGPU.

Kriesi, Hanspeter, Ruud Koopmans, and Jan Willem Duyvendak, eds. 1995. New Social Movements in Western Europe: A Comparative Analysis. Social Movements, Protest, and Contention, v. 5. Minneapolis: University of Minnesota Press.

Kriesi, Hanspeter, Ruud Koopmans, Jan Willem Duyvendak, and Marco G. Giugni. 1992. "New Social Movements and Political Opportunities in Western
Europe." European Journal of Political Research 22(2): 219-44.

Kurzman, Charles. 1996. "Structural Opportunity and Perceived Opportunity in Social-Movement Theory: The Iranian Revolution of 1979." American Sociological Review 61(1): 153-70.

Kynev, Aleksandr. 2009. Vybory Parlamentov Rossijskih Regionov 2003-2009: Pervyj Cykl Vnedrenija Proporcional'noj Izbiratel'noj Sistemy [Elections to the Parliaments of the Russian Regions 2003-2009: The First Cycle of the Introduction of Proportional Electoral System]. Moskva: Tsentr "Panorama."

— . 2014. Vybory Regional'nyh Parlamentov v Rossii 2009-2013: Ot Partizatsii k Personalizacii [Elections to the Parliaments of the Russian Regions 2009-2013: From Partyization to Personalization]. Moskva: Tsentr "Panorama."

Lankina, Tomila, Alexander Libman, and Anastassia Obydenkova. 2016. "Authoritarian and Democratic Diffusion in Post-Communist Regions." Comparative Political Studies 49(12): 1599-629.

Lankina, Tomila V. 2018. "Lankina Russian Protest Event Dataset.” Retrieved December 11, 2019. (http:// eprints.lse.ac.uk/90298/).

Laruelle, Marlene. 2013. “Conservatism as the Kremlin's New Toolkit: An Ideology at the Lowest Cost." Russian Analytical Digest 138:2-4.

Lasnier, Virginie. 2017. "Demobilisation and Its Consequences: After the Russian Movement Za Chestnye Vybory." Europe-Asia Studies 69(5): 1-23.

_ 2018. "Russia's Opposition Movement Five Years after Bolotnaia." Problems of Post-Communism 65(5): 359-71.

Levitsky, Steven, and Lucan A. Way. 2010. Competitive Authoritarianism: Hybrid Regimes after the Cold War. Problems of International Politics. Cambridge: Cambridge University Press.

Levy, Jack S. 2008. "Case Studies: Types, Designs, and Logics of Inference." Conflict Management and Peace Science 25(1): 1-18.

Libman, Alexander. 2017. "Subnational Political Regimes and Formal Economic Regulation: Evidence from Russian Regions.” Regional \& Federal Studies 27(2): 127-51.

Mahoney, James. 2000. "Path Dependence in Historical Sociology." Theory and Society 29(4): 507-48.

Maloney, William, Graham Smith, and Gerry Stoker. 2000. "Social Capital and Urban Governance: Adding a More Contextualized 'Top-down' Perspective.” Political Studies 48(4): 802-20.

McAdam, Doug. 1986. "Recruitment to High-Risk Activism: The Case of Freedom Summer." American Journal of Sociology 92(1): 64-90.

-1999. Political Process and the Development of Black Insurgency, 1930-1970. 2nd ed. Chicago: University of Chicago Press. 
McFaul, Michael, and Nikolay Petrov. 1998. "Rostovskaya Oblast'." In Politicheskiy al'manakh Rossii 1997, ed. Michael McFaul and Nikolay Petrov, 795-808. Moscow: Moscow Carnegie Center.

Meyer, David S., and Debra C. Minkoff. 2004. "Conceptualizing Political Opportunity." Social Forces 82(4): 1457-92.

Minkoff, Debra C. 1997. "The Sequencing of Social Movements.” American Sociological Review 62(5): 779.

Moser, Evelyn, and Anna Skripchenko. 2018. "Russian NGOs and Their Struggle for Legitimacy in the Face of the 'Foreign Agents' Law: Surviving in Small Ecologies." Europe-Asia Studies 70(4): 591-614.

Moss, Dana. 2014. "Repression, Response, and Contained Escalation Under 'Liberalized' Authoritarianism in Jordan." Mobilization: An International Quarterly 19(3): 261-86.

Nesekretno. 2011. "Rezoljutsija [Resolution]." Nesekretno, November 21. Retrieved July 17, 2020. (http://nesekretno.ru/social/3263/rezoluciy).

Oliver, Pamela, and Daniel Myers. 2002. "The Coevolution of Social Movements." Mobilization: An International Quarterly 8(1): 1-24.

Petrov, Nikolay, and Aleksei Titkov. 2013. "Rejting Demokratichnosti Regionov Moskovskogo Centra Karnegi: 10 Let v Stroju.” Moskva: Carnegie Endowment for International Peace.

Robertson, Graeme B. 2011. The Politics of Protest in Hybrid Regimes: Managing Dissent in Post-Communist Russia. Cambridge: Cambridge University Press.

Rohlfing, Ingo. 2012. Case Studies and Causal Inference: An Integrative Framework. London: Palgrave Macmillan.

Rosenfeld, Bryn. 2017. "Reevaluating the Middle-Class Protest Paradigm: A Case-Control Study of Democratic Protest Coalitions in Russia." American Political Science Review 111(4): 637-52.

Ross, Cameron, and Petr Panov. 2019. "The Range and Limitation of Sub-National Regime Variations under Electoral Authoritarianism: The Case of Russia." Regional \& Federal Studies 29(3): 355-80.

Rucht, Dieter. 1999. "Linking Organization and Mobilization: Michels' Iron Law of Oligarchy Reconsidered." Mobilization: An International Quarterly 4(2): 151-69.

Saikkonen, Inga A.-L. 2016. "Variation in Subnational Electoral Authoritarianism: Evidence from the Russian Federation.” Democratization 23(3): 437-58.

Schedler, Andreas. 2010. "Authoritarianism's Last Line of Defense." Journal of Democracy 21(1): 69-80.

Sewell, William H. 1996. "Historical Events as Transformations of Structures: Inventing Revolution at the Bastille." Theory and Society 25(6): 841-81.

Slater, Dan, and Erica Simmons. 2010. "Informative Regress: Critical Antecedents in Comparative Politics." Comparative Political Studies 43(7): 886-917.
Smyth, Regina, Anton Sobolev, and Irina Soboleva. 2013. "A Well-Organized Play: Symbolic Politics and the Effect of the Pro-Putin Rallies." Problems of PostCommunism 60(2): 24-39.

Snyder, Richard. 2001. "Scaling Down: The Subnational Comparative Method." Studies in Comparative International Development (SCID) 36(1): 93-110.

Soule, Sarah A., and Conny Roggeband. 2018. "Diffusion Processes Within and Across Movements." In The Wiley Blackwell Companion to Social Movements, ed. David A. Snow, Sarah A. Soule, Hanspeter Kriesi, and Holly J. McCammon, 236-51. Hoboken, NJ: John Wiley \& Sons, Ltd.

Staggenborg, Suzanne. 1998. "Social Movement Communities and Cycles of Protest: The Emergence and Maintenance of a Local Women's Movement." Social Problems 45(2): 180-204.

Sutherland, Neil, Christopher Land, and Steffen Böhm. 2014. "Anti-Leaders(Hip) in Social Movement Organizations: The Case of Autonomous Grassroots Groups." Organization 21(6): 759-81.

Tarrow, Sidney G. 1998. Power in Movement: Social Movements and Contentious Politics. 2nd ed. Cambridge Studies in Comparative Politics. New York: Cambridge University Press.

Tarrow, Sidney G., and Charles Tilly. 2007. "Contentious Politics and Social Movements." In The Oxford Handbook of Comparative Politics, ed. Carles Boix and Susan C. Stokes, 435-460. New York: Oxford University Press.

Taylor, Verta. 1989. "Social Movement Continuity: The Women's Movement in Abeyance." American Sociological Review 54(5): 761-75.

Thelen, Kathleen. 2003. "How Institutions Evolve: Insights from Comparative-Historical Analysis." In Comparative Historical Analysis in the Social Sciences, ed. James Mahoney and Dietrich Rueschemeyer, 208-40. Cambridge Studies in Comparative Politics. New York: Cambridge University Press.

- 1986. The Contentious French. Cambridge, MA: Belknap Press.

Tilly, Charles. 2008. Contentious Performances. Cambridge: Cambridge University Press.

Tucker, Joshua A. 2007. "Enough! Electoral Fraud, Collective Action Problems, and Post-Communist Colored Revolutions." Perspectives on Politics 5(3): 535-51.

White, David. 2015. "Political Opposition in Russia: The Challenges of Mobilisation and the Political-Civil Society Nexus." East European Politics 31(3): 314-25. Yevtyushkin, Aleksandr V., Yurii E. Khokhlov, and Sergei B. Shaposhnik. 2012. Indeks gotovnosti regionov Rossii k informatsionnomu obshchestvu 2010-2011 [Index of Russian Regions' Readiness for the Information Society 2010-2011], Institut razvitiya informatsionnogo obshchestva [Institute for the Development of the Information Society], Moscow. 